
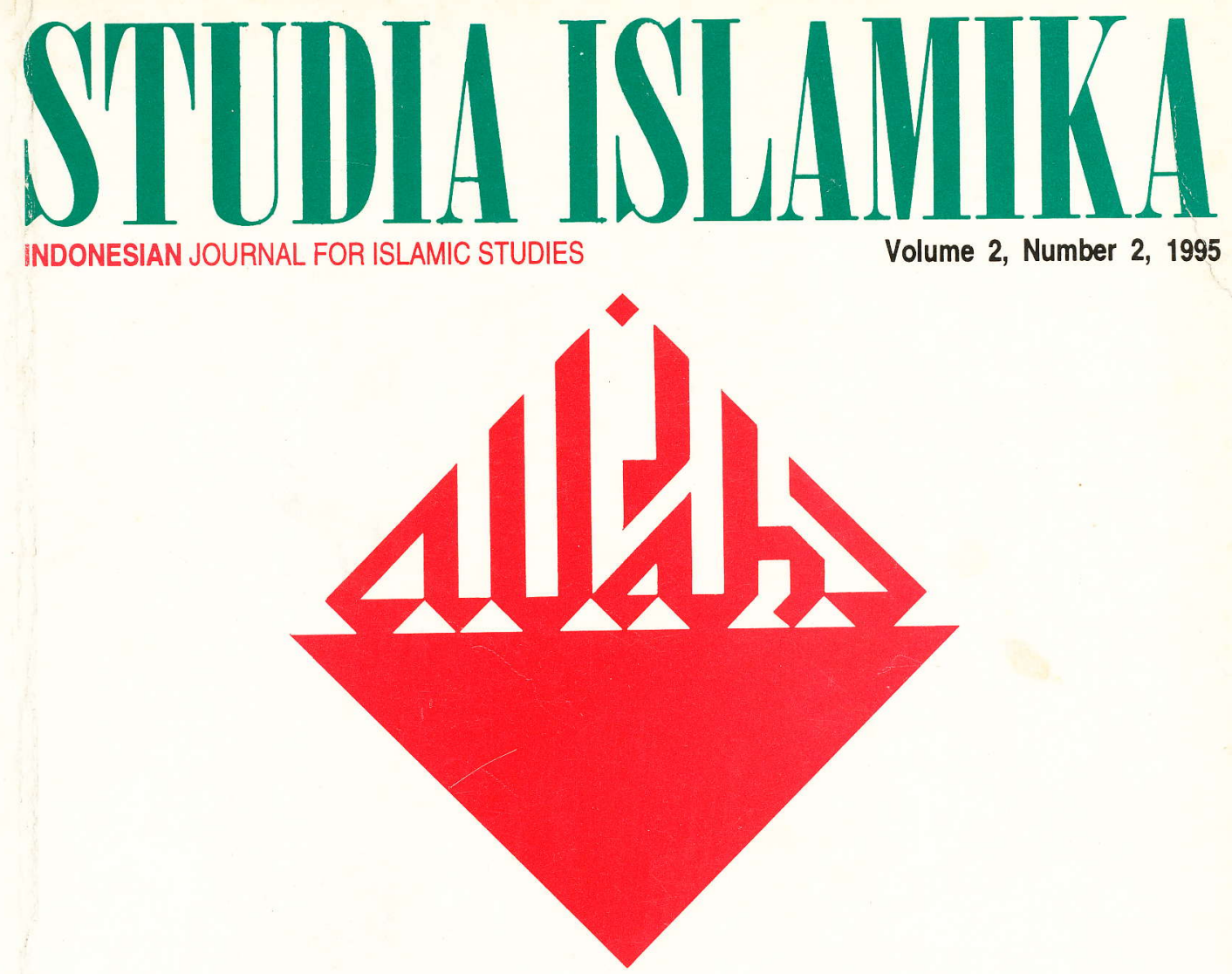

HADHRÂMÎSCHOLARS IN THE MALAY-INDONESIAN DIASPỌA:

A Preliminary Study of Sayyid 'Uthmân

Azyumardi Azra

The MUhammadiyah DA'WAH AND AlLOCATIVE POLITICS IN THE NEW ORDER M. Din Syamsuddin

QUR'ÂN INTERPRETATIONS OF HAMZAH FANSURI (CA.1600)

AND HAMKA (1908-1982): A Comparison

Karel Steenbrink

ISLAM AND THE STATE IN INDONESIA:

Munawir Sjadzali and the Development of a New Theological

Underpinning of Political Islam

Bahtiar Effendy 


\section{STIDIA ISLAMIIKI}

Indonesian Journal for Islamic Studies

Volume 2, Number 2, 1995

EDITORIAL BOARD:

Harun Nasution

Mastubu

M. Quraish Sbibab

A. Aziz Dablan

M. Satria Effendi

Nabilab Lubis

M. Yunan Yusuf

Komaruddin Hidayat

M. Din Syamsuddin

Muslim Nasution

Wabib Mu'thi

EDITOR IN CHIEF:

Azyumardi Azra

EDITORS:

Saiful Muzani

Hendro Prasetyo

Joban H, Meuleman

Nurul Fajri

Badri Yatim

ASSISTANTS TO THE EDITOR:

Arif Subban

Mucblis Ainurrafik

ENGLISH LANGUAGE ADVISOR:

Judith M. Dent

ARABIC LANGUAGE ADVISOR:

M. Fuad Fachruddin

Cover Designer:

S. Prinka

STUDIA ISLAMIKA (ISSN 0215-0492) is a journal published quarterly by the Institut Agama Islam Negeri (IAIN, The State Institute for Islamic Studies) Syarif Hidayatullah, Jakarta, (STT DEPPEN No. 129/SK/DITJEN/PPG/STT/1976) and sponsored by the Department of Religious Affairs of the Republic of Indonesia. It specializes in Indonesian Islamic studies, and is intended to communicate original researches and current issues on the subject. This journal warmly welcomes contributions from scholars of related disciplines.

All articles published do not necessarily represent the views of the journal, or other institutions to which it is affiliated. They are solely the views of the authors. 


\section{Al-Naz'ah al-Khârijiyyah fî Afkâri wa Harakâti al-Shaykh Ahmad Rifâ‘î bi Kâlî Sâlâk}

Abstract: Throughout the nineteenth and the first half of the twentieth centuries, Indonesian bistory was colored by indigenous upheavals and social protests. These events were the result of conflicts of interest between the indigenous people and the Dutch colonial government. The patterns of the emerging movements can be classified into four categories: (1) antiexploitation movements, (2) milleniaristic, including messianistic or "just king", movements, (3) revivalistic of sect movements, and (4) semi-modern movement. Most of the Islamic revivalist movements tended to be neo-Kharijite in character, which rejects the legitimate power of the existing government and its apparatus. This tendency is not only prevalent in their intellectual output, but also in their actual movements, although not necessarily manifested in terms of physical rebellion. Such is the apparent characteristics of thoughts and movements proclaimed by a prominent religious figure, $K$. H. Abmad Rifa'i.

$R$ ifa'i was a religious intellectual ('ulamâ), who spent about 20 years of his life in the Middle East, notably Mecca and Cairo, undertaking religious studies. Returning from the Middle East, he resided in Kaliwungu, Kendal, Central Java. In this place he grave his full attention to the teaching of religious knowledge and writing books. He was also active in en. couraging the students and the surrounding societies to uphold socio-religious consciousness in order to overcome the moral crisis faced by Muslims in general. He beld the view that the attitude of the colonial government had resulted in moral decadence among Indonesian Muslims. Based on this view, Rifa' $i$ launched severe criticisms to the government and of the indigenous feudal groups and nobility who supported the existence of colonial government.

Being regarded as a disrupter of social stability and a threat to exist- 
ing positions, the colonial government finally arrested and jailed Rifa'i in the Kendal and Semarang prisons. After being freed from custody, Rifa' $i$ moved to Kalisalak, a countryside area in the sub-district of Limpung, Batang, Central Java. There he established a traditional religious school (pesantren) which quitely flourished. The vast influence of $R$ ifa' $i$ can not be detached from his counter-stream teachings. He proscribed marriages which were solemnized by government-elected religious officials; be also proscribed Jum'at prayers which were conducted in mosques bulit by the colonial government. Rifa' $i$ categorized all the government religious officials as fâsiq people because they collaborated with a kaffir government. Therefore, a marriage conducted before these officials was invalid and reqired revalidation. These officials were also construed to not be competent to lead Jum'ah prayers, since fâsiq people are not able to command religious rituals, including being imâm of Jum'ah prayers.

As a result of Rifa'i's appeals, many Muslims went to Kalisalak to request reapproval of their marriages. Meanwhile, $R$ ifa 'i bimself claimed to be a "just leader" on the grounds that his position was neutral, that he was far from being a colonial collaborator, and he even challenged of the power the colonial government.

Abmad Rifa'i's activities did not cease even during bis political asylum in Ambon. On this island he wrote four books and sent letters to his followers via his son-in-law, Imam Puro. However, his absence from the midst of his disciples eventually weakened the movement, which was previously radical. The influential charisma of A bmad Rifa $i$, that functioned as the main pillar of the movement against the Dutch colonials, was no longer effective in boosting their moral courage. At the same time, being supported by indigenous bureaucrats, the colonial government tightened its control against Rifa' $i$ 's followers. This unfortunate situation finally drove them to the edge of the politico-religious arena. They withdrew themselves and built religious movements which were very different from the previous movement.

The organization which was then known as Jama' ah Rifâ'iab emerged from amongst Abmad Rifa 'i's followers. Different from Rifa' $i$ 's ideas, the successors and the adherents of this organization were not as radical as their master. They conducted the activities of Jama' $a b$ Rifâ'iyab by means of peaceful ways and avoided radical impressions. One of the movement that still being maintained was the insistence of religious activity on the establishment of pesantrens. 


\section{Al-Naz'ah al-Khârijiyyah fî Afkâri wa Harakâti al-Shaykh Ahmad Rifấî̀ bi Kâlî Sâlâk}

Abstraksi: Sepanjang abad 19 dan parub pertama abad 20, sejarab Indonesia ditandai oleb meledaknya pelbagai gejolak dan protes sosial di kalangan pribumi. Kenyataan ini dapat dipabami sebagai akibat timbulnya konflik kepentingan yang terjadi antara masyarakat pribumi dan pmerintah kolonial. Gerakan yang muncul dapat dibedakan menjadi empat kategori: (1) gerakan anti-pemerasan, (2) gerakan mileniaristik, termasuk gerakan messianistik atau ratu adil, (3) gerakan revivalistik atau sektaris, dan (4) gerakan semi-modern. Khususnya gerakan revivalis Islam yang sering muncul ke permukaan cenderung bersifat neo-Kharijis yang pada intinya menggariskan penolakan terbadap keabsahan kekuasaan penguasa berikut aparatnya. Kecenderungan tersebut tidak banya tampak pada produk-produk pemikiran, melainkan juga pada aksi kongkrit, kendati tidak sampai berwujud pemberontakan fisik. Demikian itulab yang akan terlihat dalam pemikiran dan gerakan tokoh yang bernama K.H. Abamd Rifa'i.

Rifa 'i adalab seorang 'ulamâ' yang menghabiskan umurnya selama 20 tabun untuk belajar di Timur Tengah, khususnya di Mekkah dan Kairo. Sekembalinya dari Timur Tengah, Rifa'i menetap di Kaliwungu, Kendal, Jawa Tengab. Di sana ia mencurabkan perbatian untuk mengajar ilmuilmu agama sekaligus menulis kitab. Ia pun aktif mengajak santri dan masyarakat pada umumnya untuk menumbubkan kesadaran sosialkeagamaan guna mengikis krisis moral yang tengab menimpa umat. Menurutnya, kemerosotan moral umat merupakan akibat ulab perilaku kaum kolonial Belanda. Untuk itu, A bamad Rifa'i melancarkan kritik terbadap pemerintab kolonial dan juga kaum priyayi feodal dan tradisional yang menjadi aparatnya.

Dipandang dapat mengganggu kedudukan mereka dan ketenteraman masyarakat umum, akbirnya pemerintah Belanda menangkap dan mengamankannya di penjara Kendal dan Semarang. Sebebasnya dari tabanan, ia bijrab ke Kali Salak, sebuab desa yang termasuk dalam 
kecamatan Limpung, Kabupaten Batang, Jawa Tengah. Di sana ia mendirikan pondok pesantren yang dengan segera berkembang pesat. Pangarubnya yang bertambah luas tidak dapat dilepaskan dari ajaranajarannya yang melawan arus kekuasaan. I mengharamkan perkawinan yang dilakukan oleb para penghulu yang diangkat pemerintab kolonial, begitu juga salat Jum'at di masjid-masjid yang didirikan oleh pemerintah penjajah. Alasan yang diajukan oleh Abmad Rifa' $i$ adalab karena para pengurus dan seluruh pejabat keagamaan yang diangkat oleh pemerintah kolonial dapat dikategorikan sebagai orang-orang fâsiq, karena bekerjasama dengan pemerintah kâfir. Maka perkawinan yang dilakukan di depan penghulu tidak sab bukumnya dan perlu diulang. Mereka pun tidak layak memimpin salat Jum'at, karena orang fâsiq tidak memenubi persyaratan untuk memimpin ibadah, termasuk di dalamnya menyelenggarakan salat Jum'at. Akibatnya, banyak umat Islam yang datang ke Kali Salak untuk meminta pengesaban perkawinan mereka. Abmad Rifa "i juga menyatakan diri sebagai satu-satunya pemimpin "adil" di wilayab tersebut. Kedudukannya netral, bukan antek kolonial, dan babkan menentang kekuasaan pemerintah penjajah.

Aktifitas Abmad Rifa'i tidak berbenti pada sat ia diasingkan ke Ambon. Di sana ia masib sempat menulis empat buab buku dan melayangkan surat wasiat kepada murid-muridnya melalui menantunya, Imam Puro. Namun, ketidakhadirannya di tengah-tengah pengikut setianya jelas memperlemah gerakan tersebut yang tadinya sangat radikal. Kharisma besar Abmad Rifa'i yang menjadi penopang utama kekuatan moral pengikutnya dalam melawan penjajah tidak lagi mampu mendorong semangat mereka. Pada saat yang sama, pemerintab kolonial dengan didukung oleb kalangan birokrat pribumi terus memperkuat kontrol mereka terhadap pengikut $R$ ifa $i$. Di bawah tekanan yang begitu kuat ini, kelompok Rifa'i akbirnya tersingkir dari pentas pergumulan politik-keagamaan. Mereka menarik diri dan membangun gerakan keagamaan yang sangat berbeda dari pola yang dilancarkan oleb Rifa $i$ sendiri.

Organisasi yang kemudian dikenal dengan nama Jama'ah Rifa'iyah muncul dari para bekas pengikut Abmad Rifa'i. Berbeda dari Rifa' $i$, pengganti dan pendukung gerakan ini tidak seradikal kyainya. Mereka melangsungkan kebidupan Jama'ab Rifa'iyah melalui cara-cara damai dan menjaubkan diri dari sikap radikal. Salah satu pola gerakan yang masib diteruskan oleb kelompok ini hanyalab tekanan kegiatan keagamaan pada bidang pendidikan, khususnya pendirian pusat-pusat kegiatan keagamaan yang berupa pesantren. 
مخلطين سعد

\section{النزعة الخارجية فل أفكار وحركات

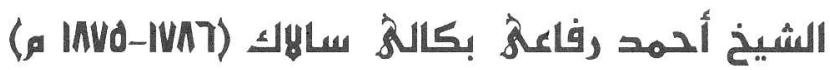

منذ دخول الاستعمار الهولندى فى أراضى إندونيسيا ظهرت عدة حركات اجتماعية

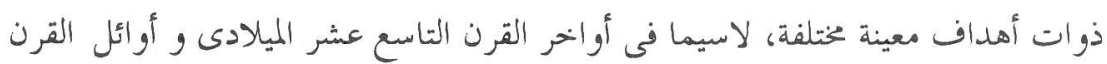

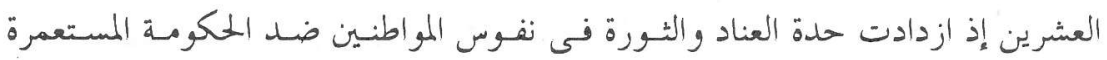

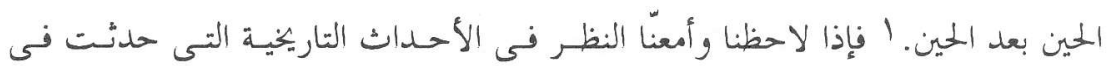

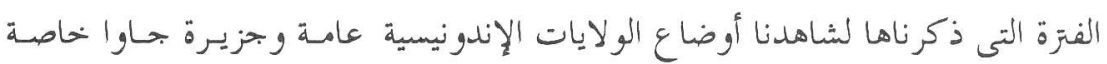

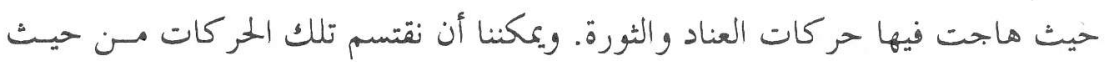

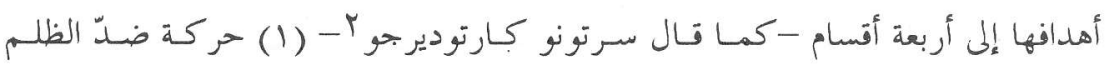

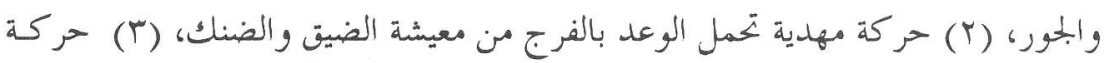
النهضة القومية، (ع) وحر كة العصر الحديث والعهد الجلديد.

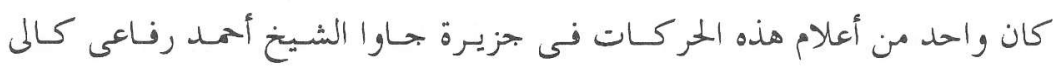
سالاك الذى بذل قصارى جهده لإصلاح المجتمع الـذى رآه مخالفـا للشـريعة الإسـلامية.

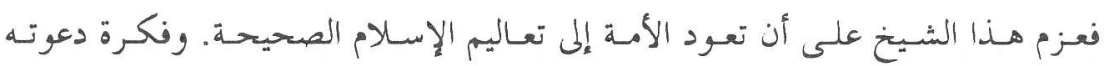
الإصلاحية كانت المقاومة ضدّ المو لانديين وحكومتهم الكافرة. وترمى هـذه الدعـوة إلى هـ

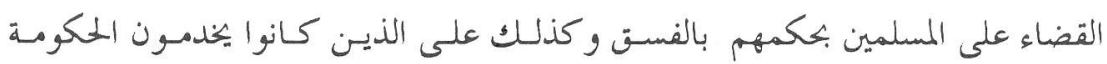

المستعمرة. واعتبر سرتونو كارتوديرجو هذه الحقيقة التاريخية هى حركة النهضية. ؟

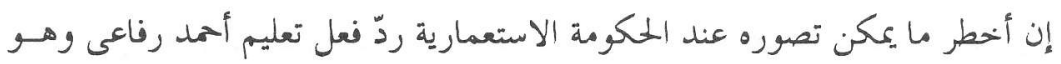

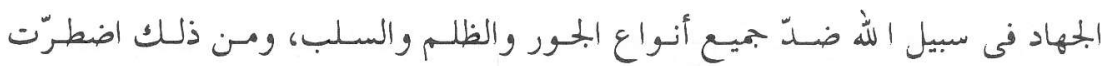


الحكومة إلى اعتبار ذلك خطرا عظيما لأمن وسلامة المجتمع. ع وأمـا حركسة هـذا الشـيخ

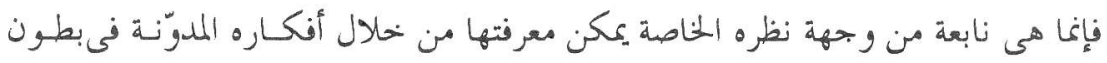

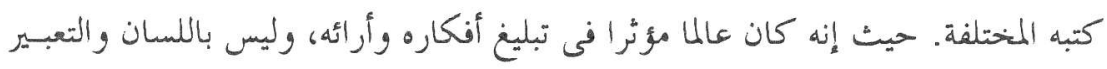
فحسب بل أيضا بالكتابة. إنه معروف بإنتاجسه الغزير في تـأليف المصنفـات التى بلغ

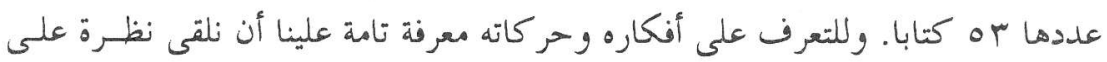
حياته.

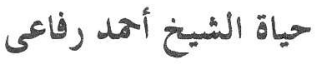

ولد أحمد رفاعى فى قرية تمفوران الو اقعة على منطقة كنـدال بجاوا الوسطى فى هـ 9

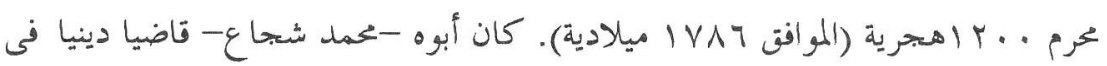

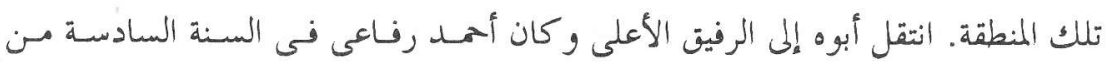

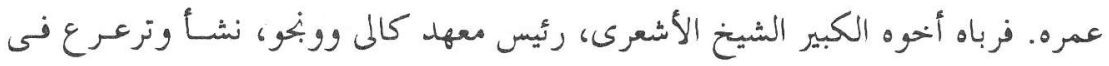
بيئة دينية صميمة.

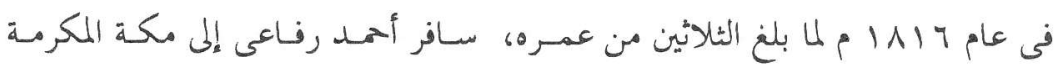

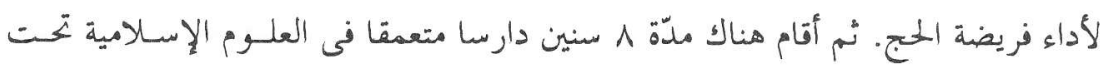

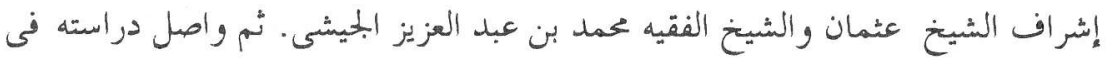
مصر لمدّة مديدة لا تقل عن Y I سنة. وفى القاهرة قام بدراسة كتب الفقه على المذهـبـ

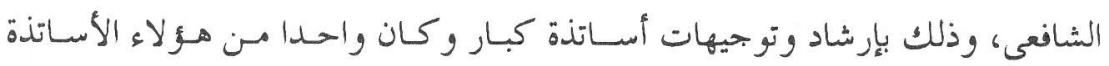

$$
\text { الشيخ إبراهيم الباجورى. }
$$

مرت عشرون سنة من دراسته فى الشرق الأوسط. ثم رجع أحمـد رفـاعى إلى جـاوا

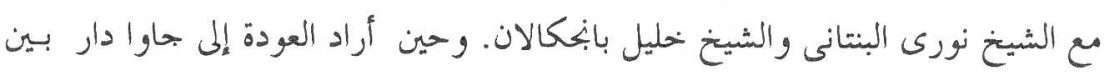

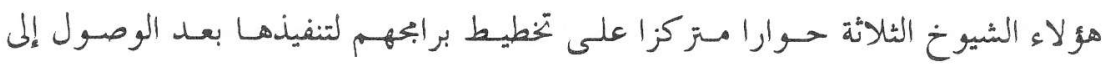

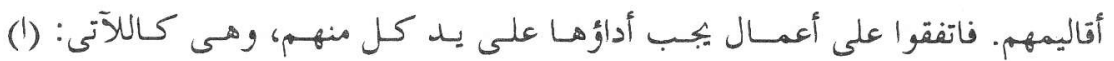

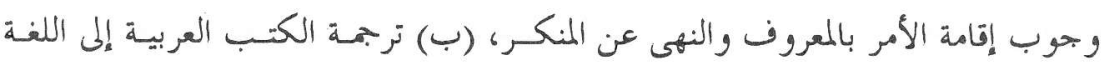

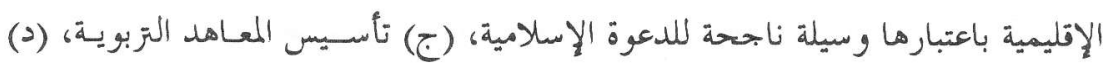


والجهاد فى سبيل الله لطرد المستعمرين من البلاد. ورغـــــلك أجمعوا على أن يكـون

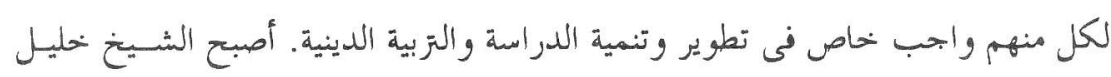

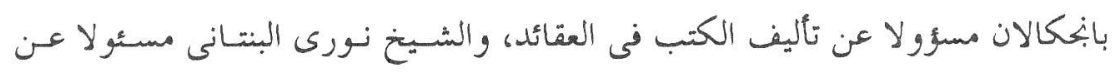

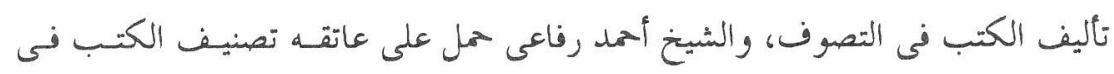
الفقه.

وقضى اثنان من هؤلاء العلماء الثلائة أيام حياتهما فى وطنهما. وأمسا الشّيخ نسورى

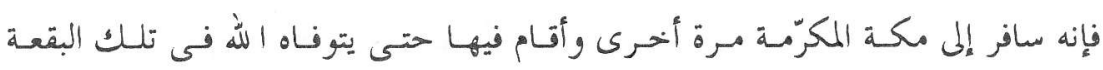

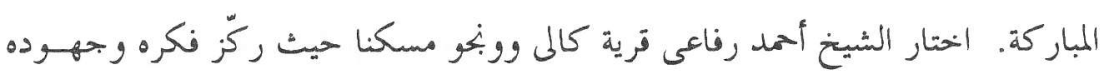

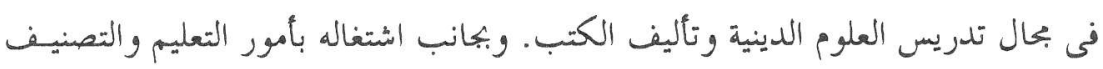

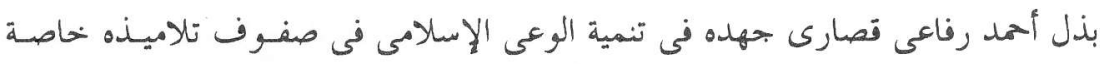

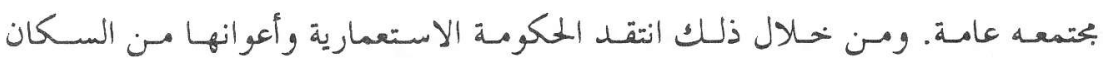

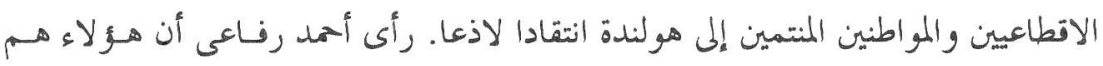

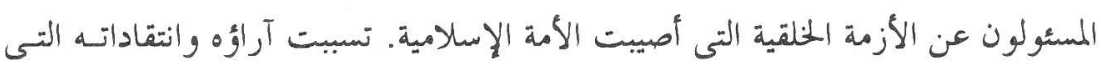

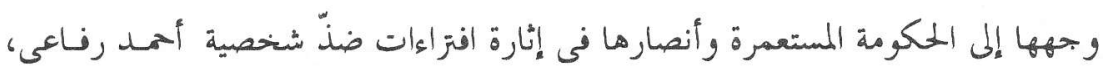

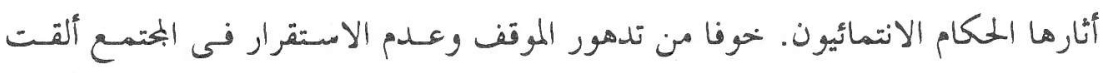
الحكومة الهولندية القبض على أحمد رفاعى ووضعته فى سجن كندال وسمار انج. ^

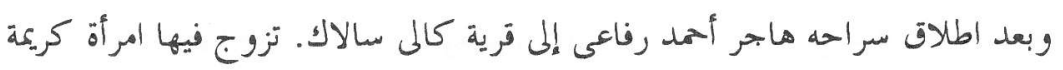

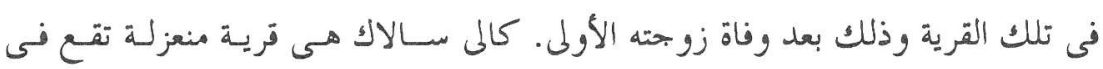

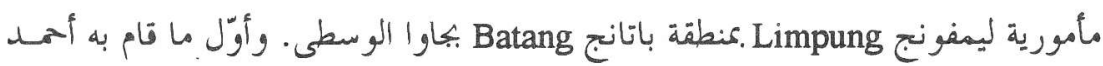

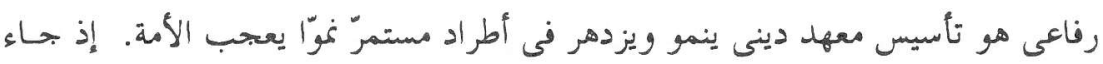

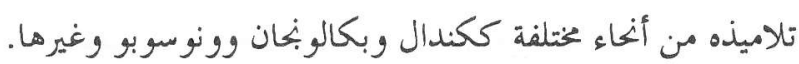

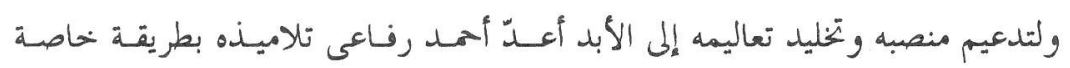

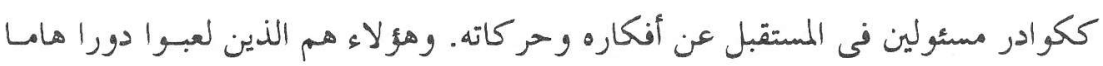

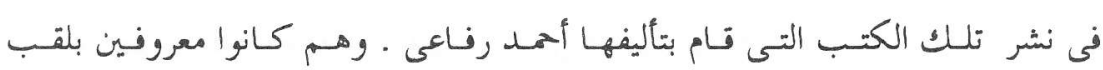

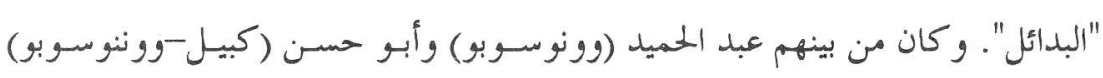




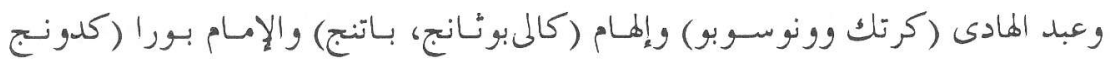

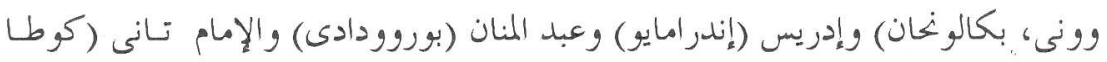

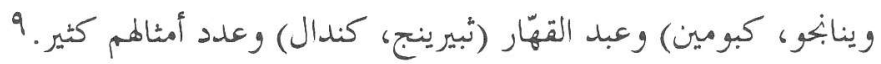

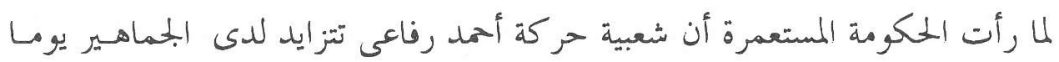

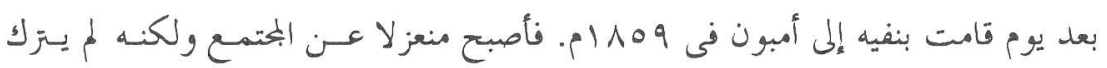

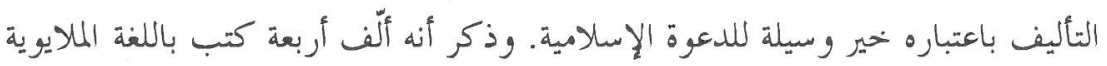

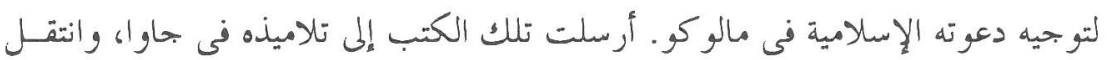

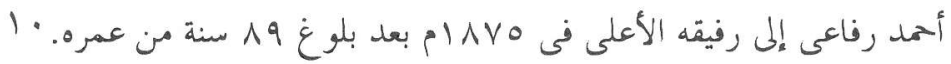

\section{أفكاره بين الإصلاح وإبداء الحججة}

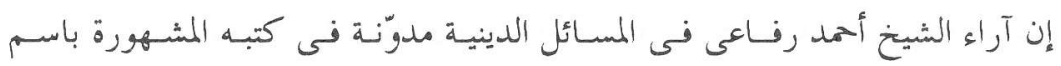

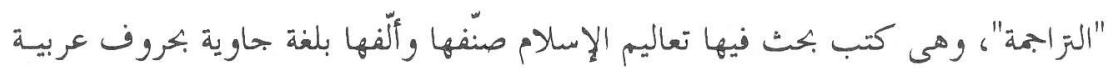
Arab Pegon

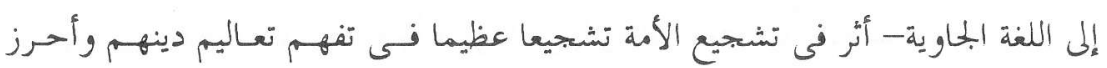

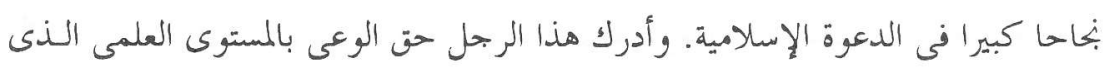

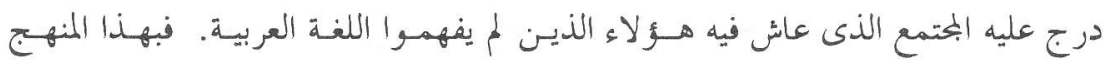

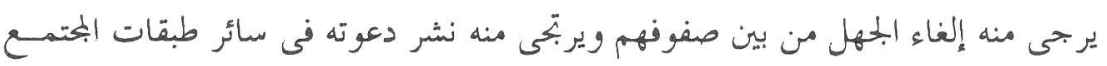

\section{خو اصهم وعو امهم.}

فباستعمال اللغة الجاوية وبتنظيم أفكاره على شكل شعر وقصائد أمكنه القيام بتبليـغ آرائه بسهولة، لأن أغلبية الجاوين قد فهمت تلك التعاليم الدينيسة التى تضمنتها كتبـهـ

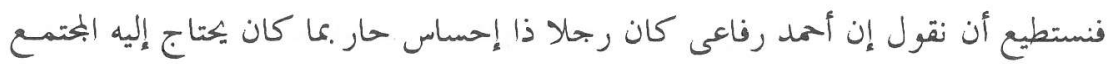

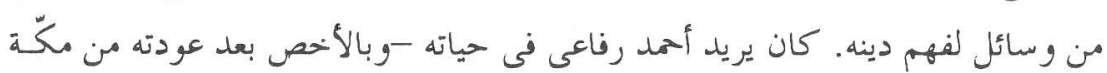
المكرمة- إذ ينتهز الفرصة لتأليف الكتب لا يقل عددها عن به مهن كتابا.

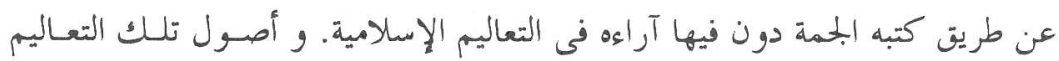

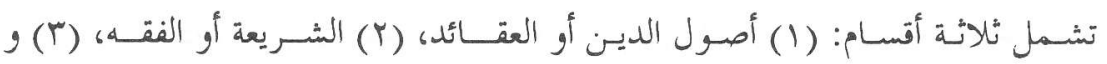


التصوف. وأشار إلى هذه الأقسام الثلاثة في الأبيات التى نقلها كـارل ا. سـتينبرينك

11:Karel A. Steenbrink

$$
\text { يشمل العلم على ثلآثة أمور }
$$

ونذكر الآن كل و واحد من تلك الأقسام الثلاثة بإيماز:

$$
\text { (1) }
$$

إن أصول الدين والعقيدة التى اعتنقها وقام بنشرها أحمد رفاعى تسلك نهج المذهــب

السنى. ويتضح هذا الأمر إذا وضعنا نصب أعيننا ما قاله الثيخ فى كتابه "رعاية الهمة":

$$
\begin{aligned}
& \text { والعالم المختهد المطلق فى أصول الدين }
\end{aligned}
$$

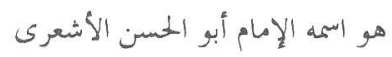

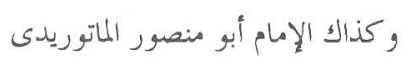

$$
\begin{aligned}
& \text { فتعاليم هذين الشيخين تبنىء عن القرأن والسنة } \\
& \text { فلذاك صحَ اتباع كليهما }
\end{aligned}
$$

ودعا أحمد رفاعى المسلمين المكلفين إلى التمسك بعقيدة أهل السنة والجماعة، فقال:

$$
\text { على ضوء لكل مسلم مكلف اعتناق دين الله }
$$

رأى هذا الشيخ أن تقليد الآخرين بدون دليل أو مصـدر غـير معتبر وغـير مقبـول، لأن

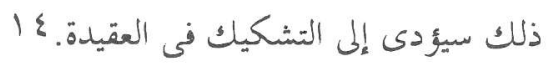

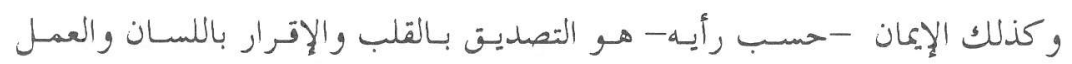

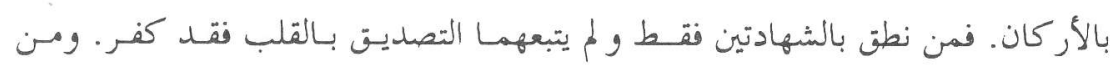




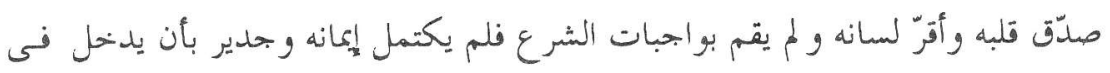

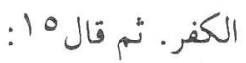

تنبه أنت أن التسليم هو موجب صحّة الإيمان. - مان.

ولإيمان كما ذكره فى كتب "التراجمة" سـتة أركان هي: (1) الإيمان بـا لله، (r)

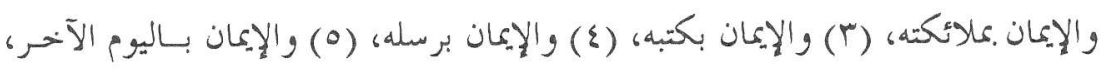
(7) والإيمان بالقدر خيره وشره. 17 وفى البحث عن الإيمان بالله ورسله وصفـات كـل

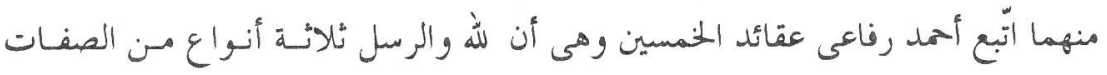

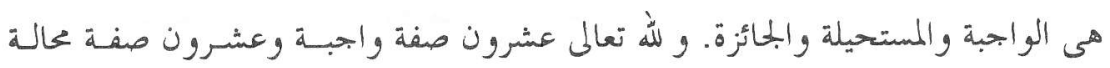

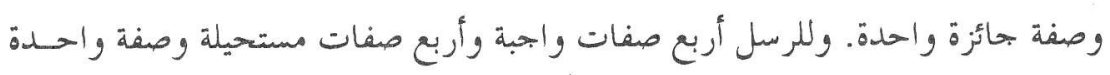

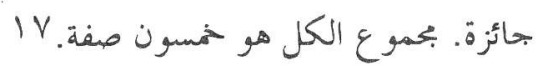
وفى مشكلة أفعال العباد انتقد أحمد رفاعى انتقادا لاذعــا مذهـب المجبريـة والقدريـة.

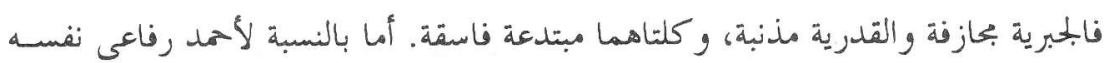

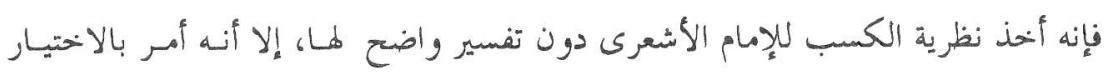

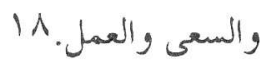

فاتضح لنا أن تعاليمه فى أصول الدين بسيطة وغير معقدة، وكانت كافية وقتئذ لسدّ

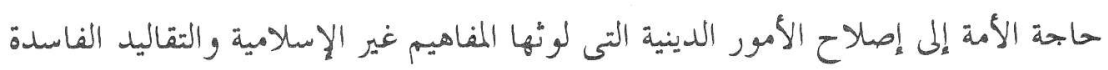

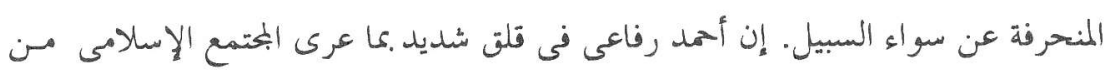

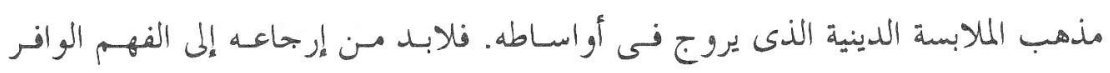

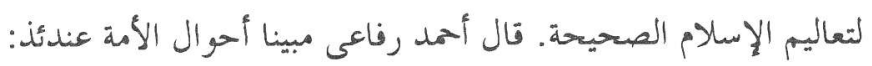

$$
\begin{aligned}
& \text { إنهم يتظاهرون بأنهم مسلمون }
\end{aligned}
$$

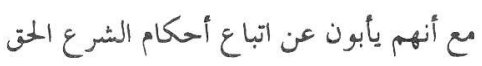

$$
\begin{aligned}
& \text { يقلدون عادات البلاد }
\end{aligned}
$$


وقلوبهم مصابة بداء الكفر. 19

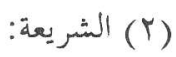

يمكن -فى الغالب- توزيع الفقه عند أحمد رفاعى إلى أربعة أبـواب: (1) العبادات،

(Y) و المعاملات، (ب) و المناكحات، (ع) و الفرائض. وأفكاره الفقهية مسسجلة في كتبـه الفقهية الكبيرة من حيث المجمى واتى تشرح إقسام التعاليم الإسلامية الثلائة بشكل عام وفى كتبه الصغيرة من حيث الحجمه، كباب المناكحات ذكره في كتابه "تبيين الإصلاح" r. بإيضاح وشرح وافت

البحو ث الفقهية التى قلمها أحمد رفاعى دارت حول الأصول بالتز كيز على مسبائل الأر كان و الشروط التى هي أساس العبادات العملية. و كان هدفه من هذه الخطبة تيسـير أحكام الدين ليفهمها الجميع من العوام و الحو اص، ويرجعـون إلى وعيهـم وذلك امتشالا بأوامره . إن آراء أحمد رفاعى فى الأحكام الشرعية تشماير مع الفقه الشافعى المـدوّن فى مي

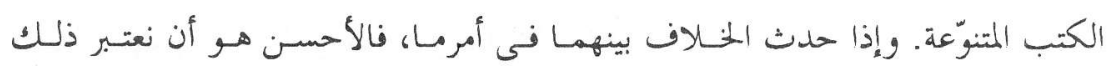
اجتهادا فرديا لهذا الشيخ لتطابق أراؤه مع الحاجة و الظاهرة الاجتماعية للأمة. فنجد مسن بين تعاليمه الفقهية ما يؤدى إلى النزاع كما يلى:

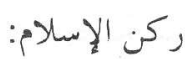

اعتقد أحمد رفاعى أن ركن الإسلام وراحد كما قال ذلك فى كتابه:

$$
\begin{aligned}
& \text { وركن الإسلام واحد لا غير } \\
& \text { هو النطق بالشهادتين } \\
& \text { كشرط صحمة الإيمان والحصول على السعادة الأخروية } \\
& \text { ولابد من تصديق القلب تصديقا متينا. } \\
& \text { ومع ذلك كتب أحمد رفاعى فى أبيات شعره الأخرى: } \\
& \text { إن تنفيذ أصول تعاليم الإسلام }
\end{aligned}
$$


يشمل النطق بالشهادين

وإقامة الصلاة وإيتاء الز كاة

وصوم رمضان وحجّ البيت

لمن استطاع إليه سبيلا.

وأما بالنسبة إلى ركن الإسلام إلهام

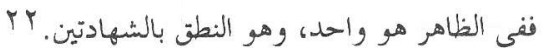

إن رأى أحمد رفاعى أن ركن الإسلام واحسـد هـو في معنى الشـرطية أى أن ذلك

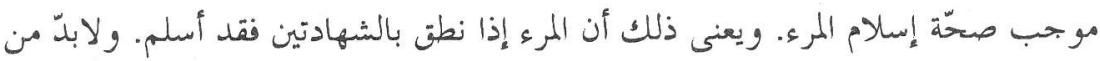

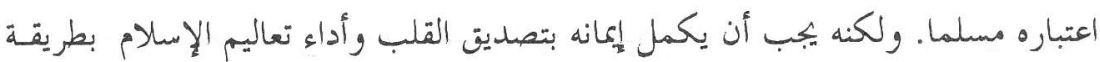
مسنونة. وأما أر كان الإسلام الأربعة الأخرى فسماها أحمد رفاعى "بعملية الإسلام". فما أرحب صدر أحمد رفاعى .عا قال هؤلاء الذين نطقوا بالشهادتين فقط و لم ينفذوا

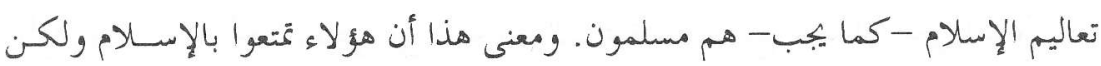
يجب عليهم إتمام ما نقص من شروط الإيمان با لله.

\section{(ب) النكاح (ب)}

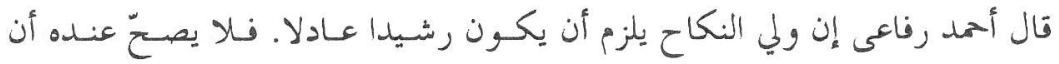

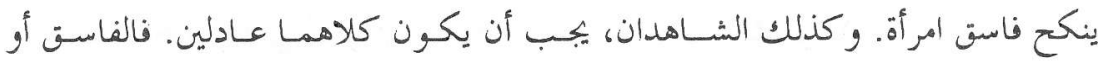

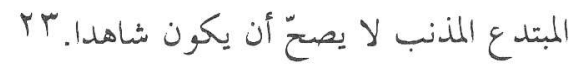

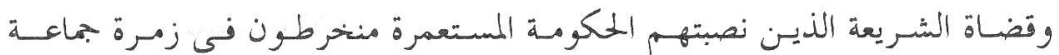

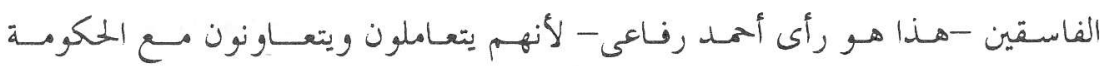

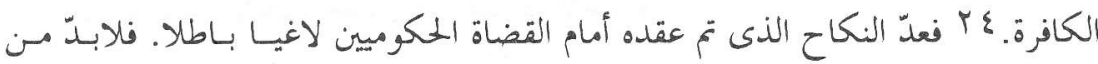

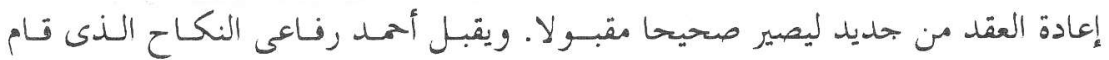
بعقده ولى فاسق مع استحباب إعادة العقد وتحديده. قال أحمد رفاعى:

$$
\text { بتصحّ لوليّ فاسق إنكاح }
$$




$$
\begin{aligned}
& \text { مشقة إحضار وليّ صادق }
\end{aligned}
$$

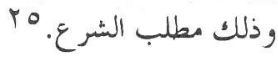

$$
\text { (ج) }
$$

تمسّك أحمد رفاعى بأن عدد المصلين الذين تصح بهم صلاة المجمعة هو أربعون رجلا أحرارا غير أمّينن عالمين بشروط وأركان المجمعة. وإذا نقص أحد هذه الشّروط لم تصـحّ صالاة الجمعة. فرق أحمد رفاعى فى هذا المبحث بين أهل الجمعة وعـدد الجمعـة وجماعـة الجمعةة. قأهل الجمعة هم مكلفون بأداء صالاة الجمعة صالة صحيحة. وأما جماعة الجمعسة فهى عبارة عمن يشّتر كون في إقامة المجمعة كالأولاد الصفار.

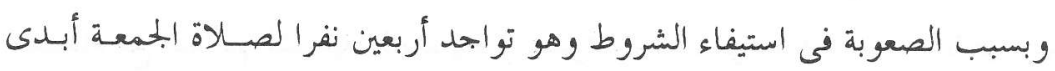
أحمد رفاعى رأيا آخر وهو أن صلاة الجمعة تعتبر صلاة صحيحة حين يبلغ علد المصلّـين

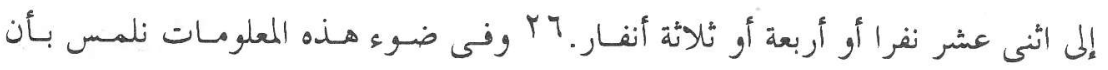

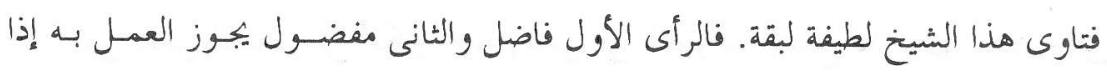
فقل الأوّل. وأما انتقاد أحمد رفاعى صحّة صلاة المجمعـة التى كـانت تقّام فى مسـاجد الحلكومة المستعمرة فلا يرجع إلى أنها لا تنبنى على فكرة ما عن صلاة الجمعة نفسها بـل

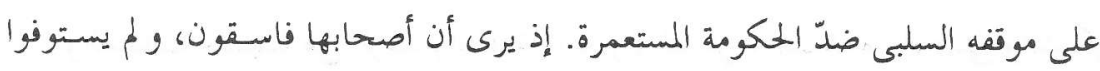
الشروط المطلوبة لإقامة العبادات كإقامة صلاة المجمعة.

وعن التصوّف يقول أحمـل رفـاعى إنسه علهم يبحث عـن أخهالاق الإنسبـان المهمـودة والمذمومة لينال به رضا الله تعالى. ذكر فى بعض أبياته:

$$
\text { إن علم التصوّف هو }
$$

معرفة الصفات بعضها محمودة

$$
\text { وبعضها مذمومة في القلب }
$$

ليكون القصد خحالصا لله تعالى. 
والهدف السامى للتصوّف هو تطهير القلب وتز كيته ليستقيم التوجّهـ إلى الله فحسبـ.

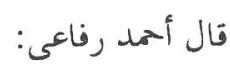

$$
\begin{aligned}
& \text { وأما علم التصوّف المذكور } \\
& \text { فهو أمر تطهير القلب العزيز }
\end{aligned}
$$

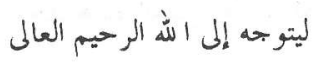

$$
\begin{aligned}
& \text { وما سوى الله فهو باطل منكر . له لرحبم العال }
\end{aligned}
$$

تأييدا لمذهب أهل السنة والجماعة سارت مبـاحث أحمـد رفـاعى عـن التصـوف فى

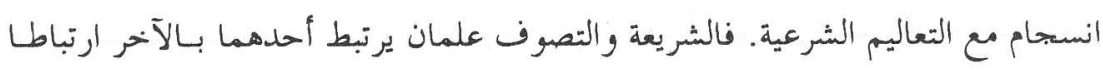

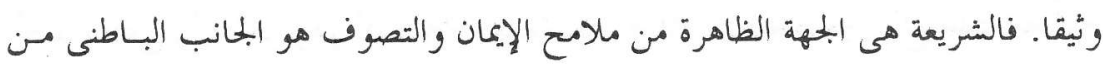
مآثر الإيمان.

نلقى بعض الضوء على أفكار أحمد رفاعى فى التصوف ليتضح لنا مدى استقامته فى النى اتباع الثريعة وابتعاده عن النظريات الصوفية المعقدة:

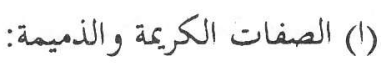

والصفات الحميدة هى الزهد و القناعة والصبر والتوكّل و البحساهدة والرضى و الشـكر والإخحلاص. قال أحمد رفاعى:

$$
\begin{aligned}
& \text { من الصفات المحمودة عند الشرع } \\
& \text { هذه الأمور الثمانية الآتية }
\end{aligned}
$$

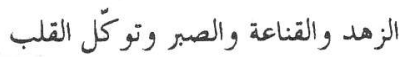

$$
\begin{aligned}
& \text { والمحاهدة والرضى والشكر وإخلاص النية }
\end{aligned}
$$

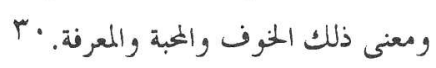

و الأخحلاق التالية من نوع الصفات المذمومة، وهى حـب الدنيـا والطمـع واتبـاع الهـوى

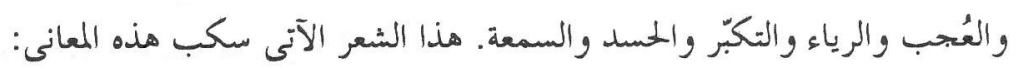




$$
\begin{aligned}
& \text { وبيان بعض الصفات المذمومة } \\
& \text { التى تفسد القلوب عند الشيرع } \\
& \text { وهى ثمانية أمور سيأتى بيانها } \\
& \text { حب الدنيا والطمع وثالثها اتباع الهوى } \\
& \text { والعجب والرياء والتكبر و الحسدد والسمعة } \\
& \text { فالقلب سيعلمها غدا } \\
& \text { إن شاء الذ بمعونته تعالى }
\end{aligned}
$$

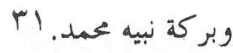$$
\text { ف) المبر }
$$

والمعرفة فى نظر أحمد رفاعى هى التفكّر فى تدرة الله تعـالى أو حـال القلـب الـذى

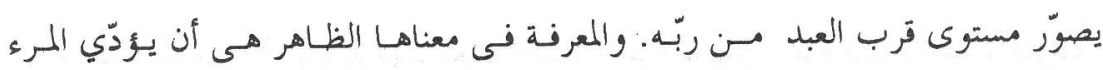
الواجبات الدينية المناسبة بالشرع مع إخلاص القلب لله تعالى. فالعارف كلما نال مدحا من المؤمنين لحسناته ازداد إيمانا وشكرا المولاه تعالى.

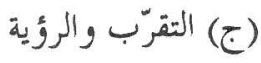

يجب على المؤمن الحقيقى أن يبذل كل ما فى وسعه فى سبيل تقريب نفسه مـ الله عزّ وجلّ. فمن يسعى للتقرّب إليه تعالى يجب عليه أن يسلك طريت المعرفة. فعـدّ الز اهـــ

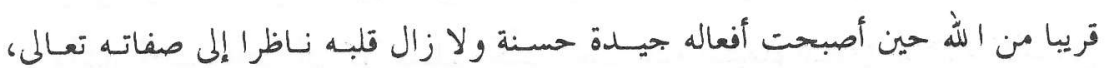
جعل الحوف سوطا فى خلفه والمحبة لجامـا فى إمانه هاديـا إلى الله فى طلـب مرضاتس ومالوذه تعالى ومهما بلغ العبد الدرجة العليا من المعرفة والتقرب إلى الله، لا يمكن له أن يرى ذاتسه تعالى. و العبد الذى رأى الله تعالى فى هذه الديا وحيد لا غير وهو محمّل صلّى الله عليه

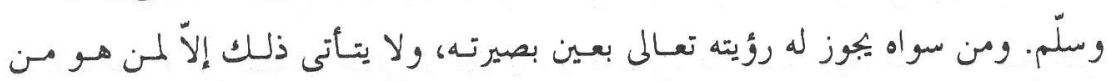
الأولياء ذوى أوصاف معينة. بr 


\section{(2) وليّ الهُ (2)}

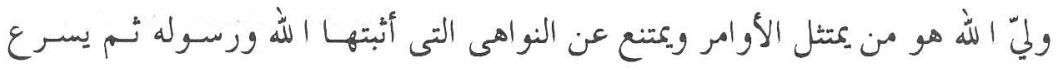

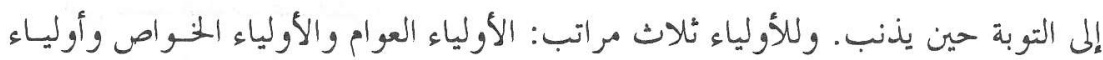

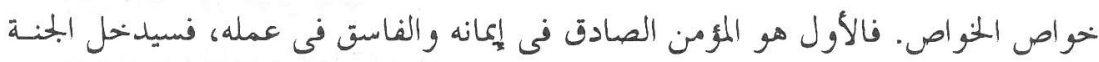

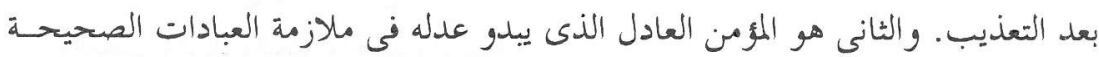

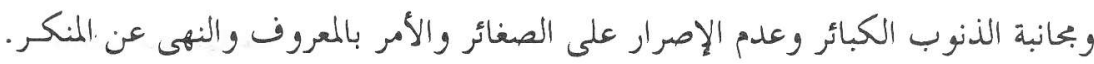

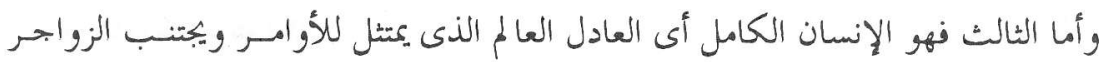

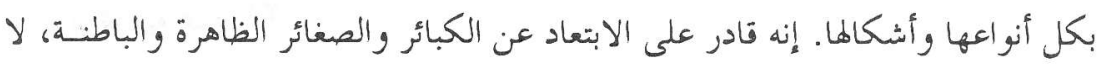

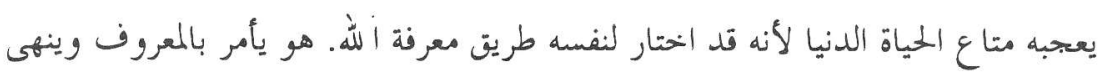

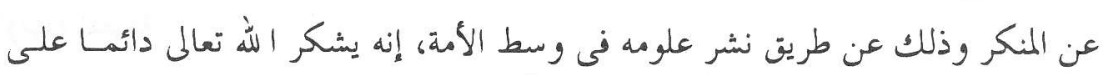

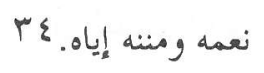
والضعاف من الأولياء يلزمهم العزلة حيث لا قوة لديهم لدعوة دينه وتعليـم علومـهـ.

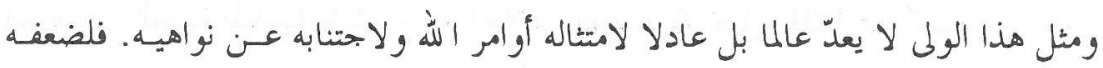

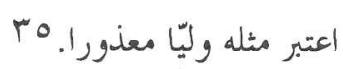

(0) الصلة بين الشريعة والطريقة والحقيقة:

هناك صلة متحدة لا يمكن فصلها بين الشريعة والطريقة والمقيقة. هذه المبادئ الثلاثة

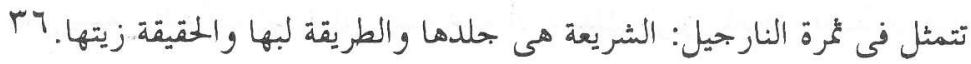

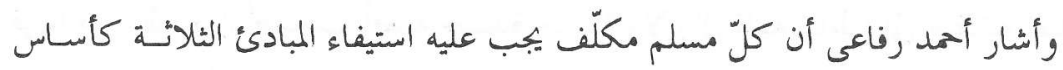

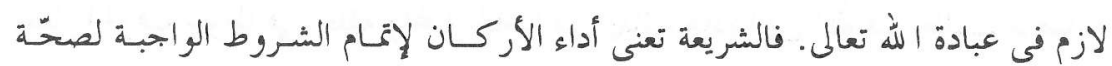

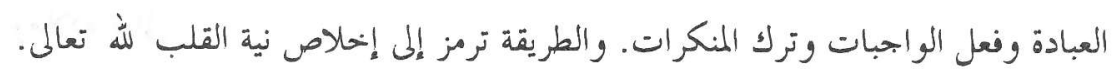
والحقيقة هي عبارة عن ابتغاء رحمته ومعونته تعالى.

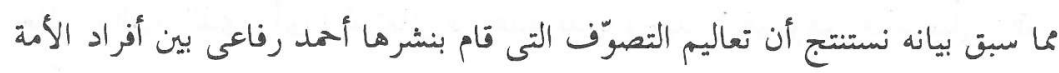

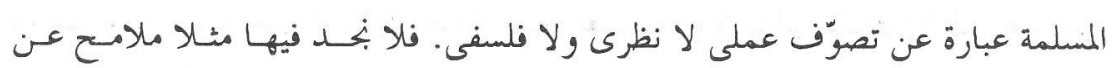

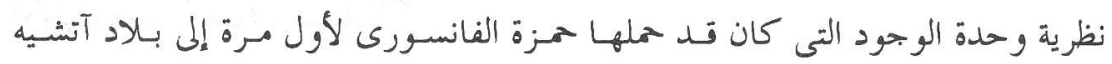


Aceh فى القرن السادس عشر، ولعلّ ما دفعه إلى ذلــك هـو همتـه العاليـة لتغيـير عقليـة

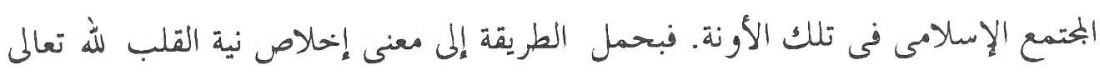

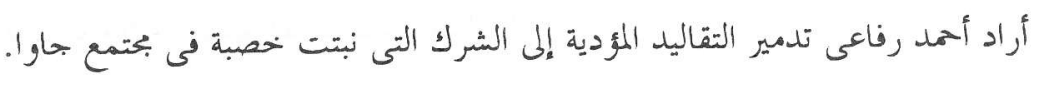

\section{حر كاته والنزعة الحارجية الجلديدة}

قد ذكرنا فيما مضى أن أحمد رفاعى بعد عودته إلى جاوا سكن هنالك ويعلّم العلوم

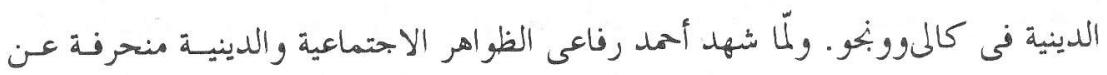
التعاليم الشرعية، فاقت نفسه وقامت عزيمته للمجاهدة فى إصلاح التقاليد التى لا علاقته

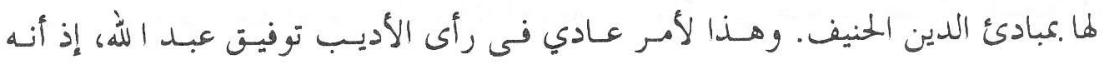

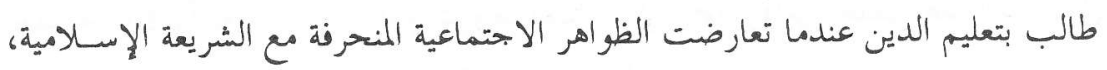

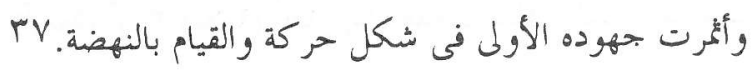
وأوّل ما قام به هو تأليف الكتب (الشهيرة باسم "التزاجمـة") وتعليمم العلوم الدينيـة

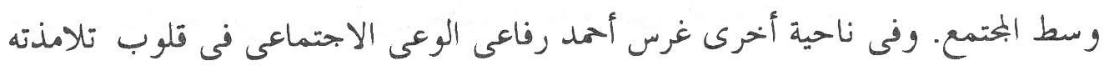

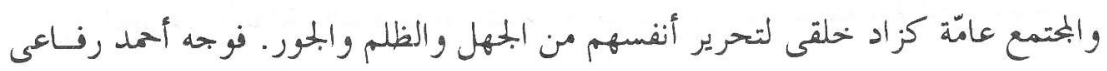

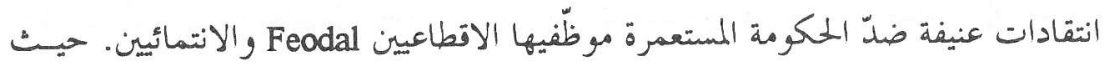

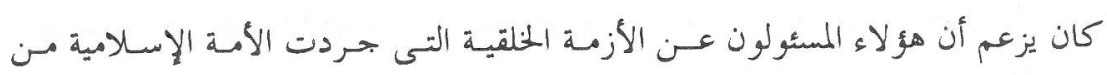

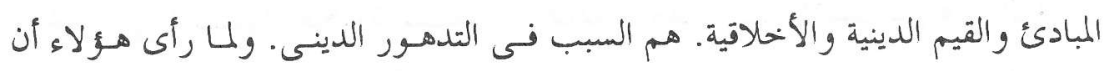

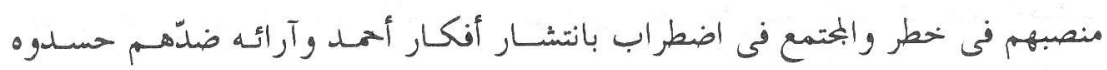
وافتروا عليه فألقت الحكومة الهولندية القبض عليه وسجنته في كندال وسمارانج.

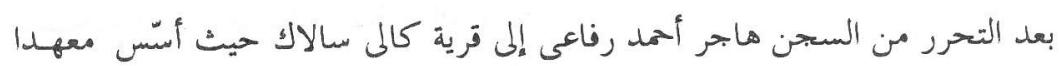

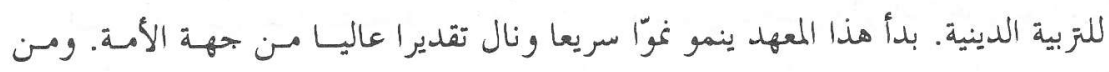

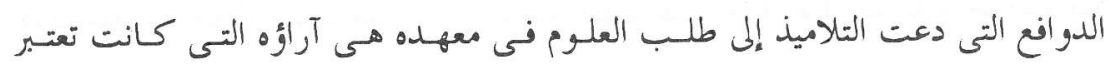

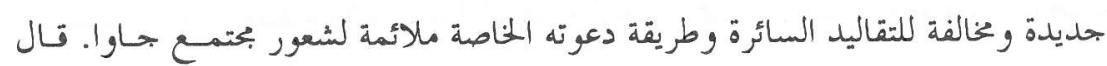
أحمد رفاعى فى بعض أشعاره: 
هو النطق بالشُهادتين

كشرط لصحة الإيمان ولنيل السعادة الأخروية

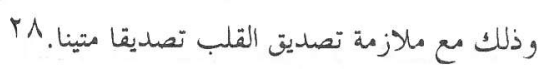

فبالطبع كان هذا التعليم جذابا لقلوب العامّة هـن السـكان الجـاويين الذيـن مـاز الوا يعيشون تحت ضغوط الأفكار الدينية الزائفة. وفى الحقيقة لا يريد أحمد رفاعى بقوله "إن ركن الإسلام و احد" رفض الأركان الأربعة الأخرى من الأركان الخمسة، بل أنسه اهتـمّم في بيت أخر من شعره بأهمية أركان الإسلام الأربعة الأخرى للإسلام. وظهـرت أيضـا رحابة دعوته في اعتقاده عن أداء صلاة الجمعة. بالجملة التى صحمّت صلاة الجمعــة إذا حضرها . ع (أربعون) رجالا ذور شروط معينة. لكن أحمد رفاعى حفض هذا العـدد إلى

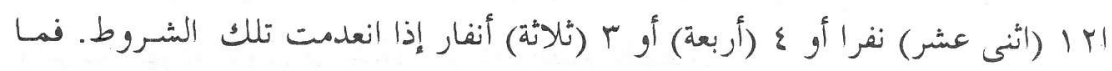
أوفق وما أرشق هذا الطريق للعوته، ولاسيما عند استخداهه اللغة الجاوية لتأليف كتبـه. فهذا قد ساعده على نشر وقبول تعاليم الإسلام لدى المختمع البحاوى. إن الظو اهـر البيئيـة والشَئون الاجتماعيـة كـانت غـير مستقيمة و ولم تكـن معالجتهـا

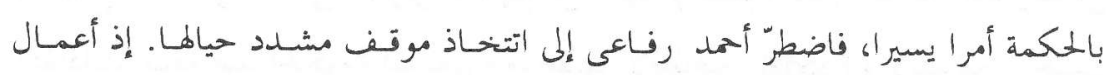

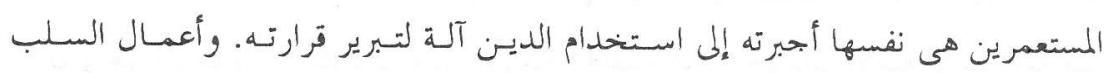

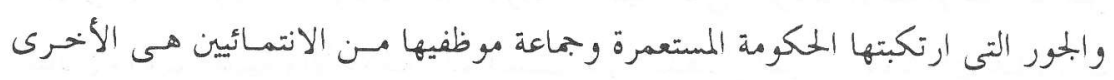
دفعت أحمد رفاعى إلى ابراز الأحكام باسم الدين. ففى مثل تلك الظروف ظهر الجـانب

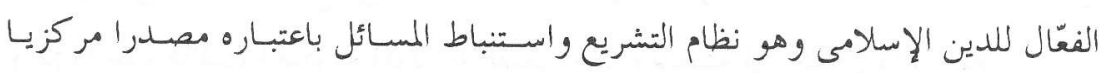
لتصسيح المسير نخو نظام الفكر و العمل. ليس بأمر يسير لهذا الشيخ قبول الحكم على المسلمين بالفسق والرئاسة عليهـم دينيـا

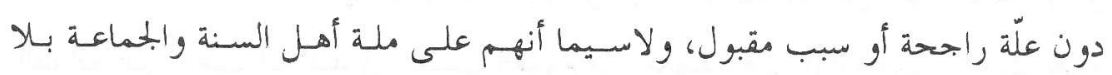

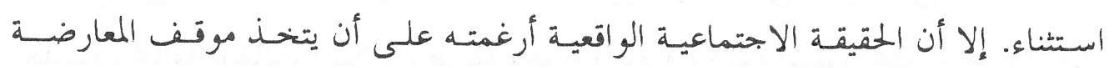

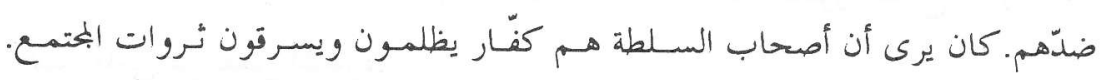
والموظفون الإقليميون يساعدو نهم فى هـذه الأعمـال التخريبية، ومـن ضمنهـم موظفو

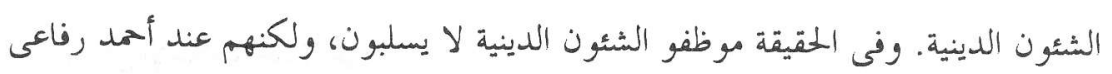


يتعاونون دائما مع الحكومة المستعمرة. ففى هذه القضية نلمسس جـدوث الانسـام بين المهمة الاجتماعية والمهمة الدينية فى حركة واحسدة هي حركمة وينيـة. وبتو حيـد هـاتين

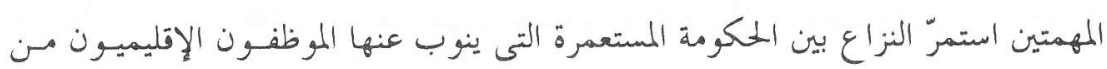
جهة وحر كة أحمد رفاعى من جهة أخرى.

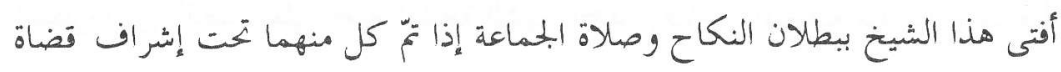

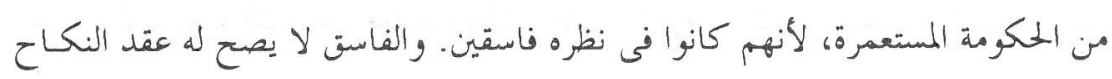

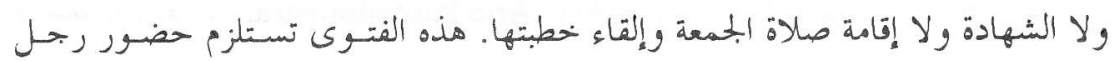

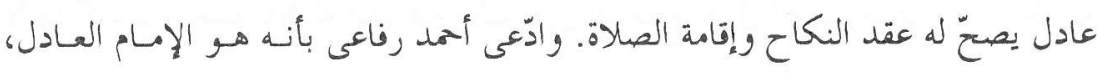

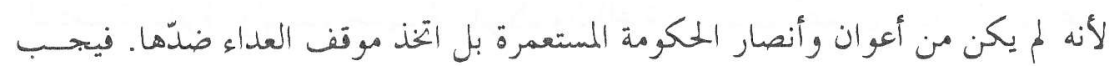

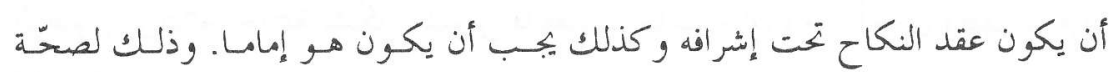

$$
\text { النكاح و الصلاة. }
$$

فاتشر ما ادعاه به أحمد رفاعى بين صفوف ابنـاء الأمـة. وبالتـالى تـأثرت بـه قلـوب

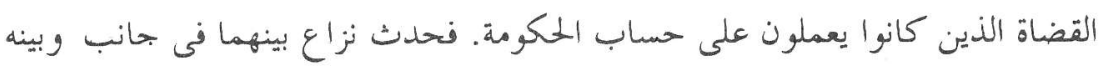

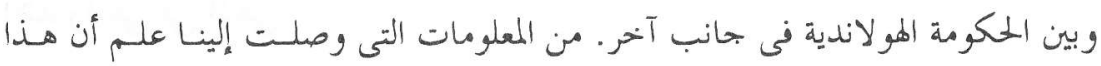

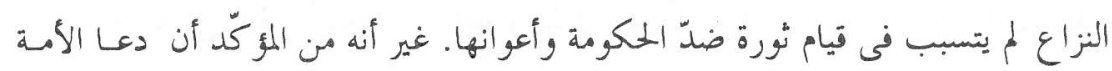

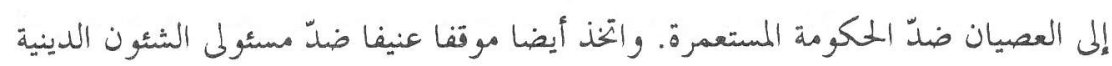

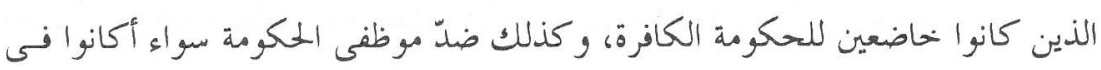

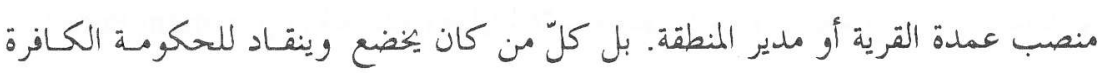

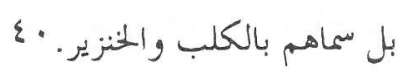

إن تعاليم أحمد رفاعى -التى أبلغها للشعب بواسطة خطب الجمعة وبحالسه العلمية--

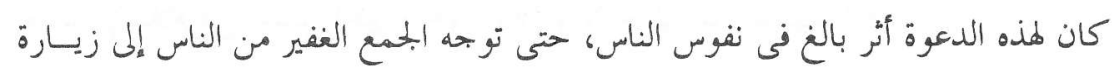

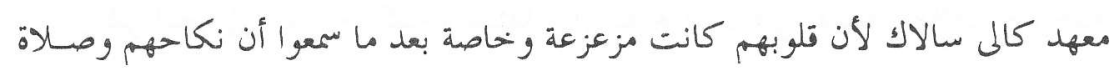
جمتهم باطلة. وذلك لتطمئن نفوسهم المضطربة بشهادة هذا الشيخ بصحة إسلامهم.

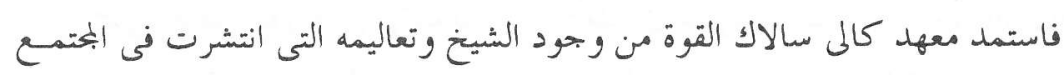

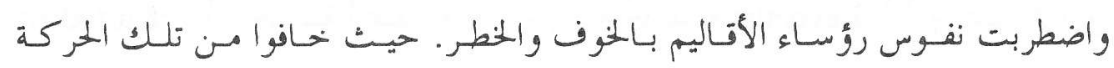


المعارضة التى قام بتكوينها أحمد رفاعى وتلك الحركة كانت متمثلـة في حركـة ثوريـة.

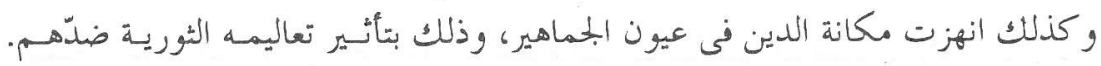

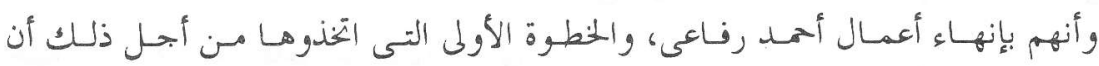

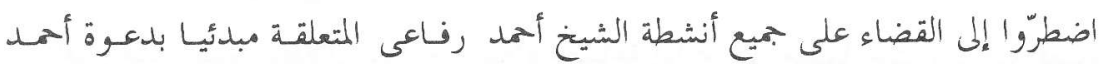

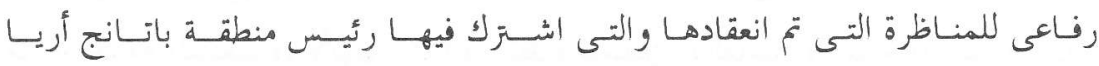

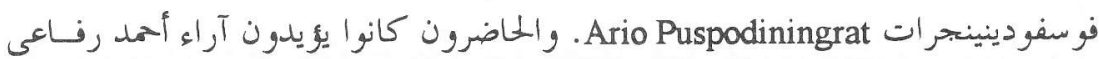

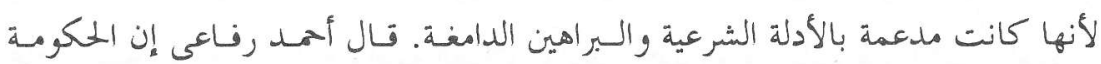

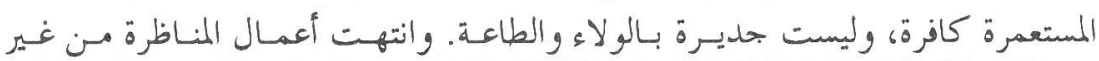

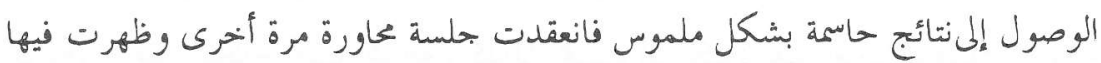

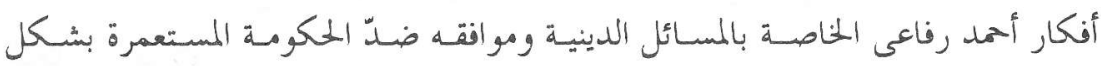

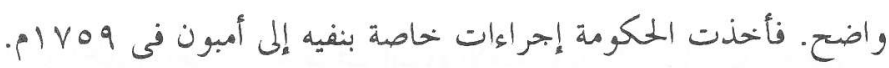

\section{أحمد رفاعى فى المنفى}

إن حياته فى المنفى أضعفت نشاطه ولذلك نرى أن الكتب التى ألّفها فى تلك المـدة

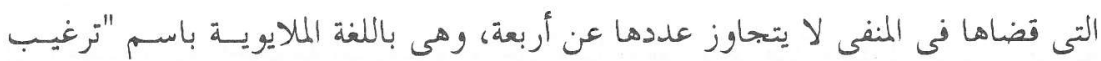

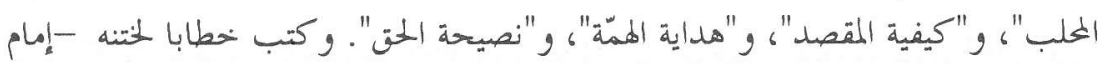

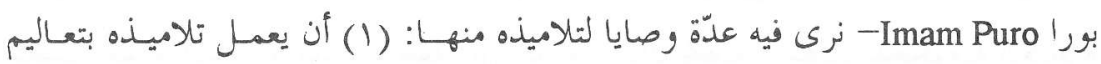

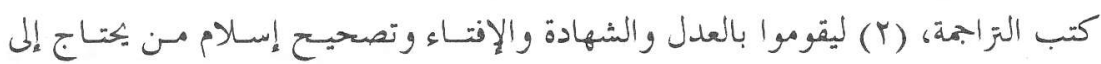

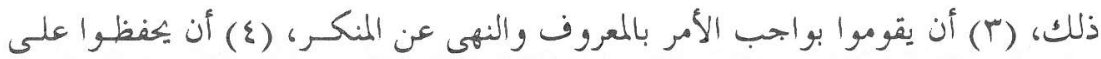

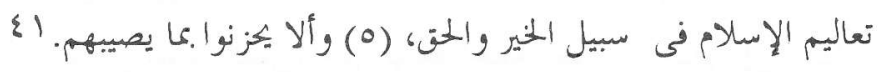

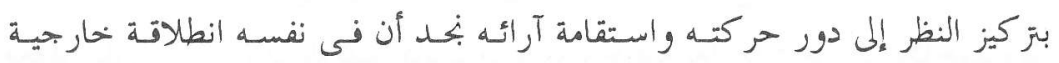
جديدة، وكانت تلك الانطلاقة نتيجة طبيعية لتجاوبه مع الحقائق الاجتماعية التى قابلها

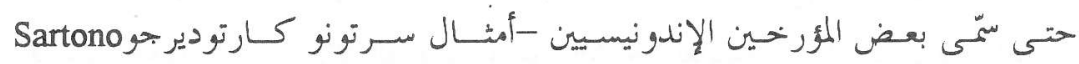

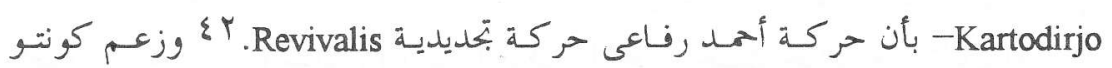


وييويو Kuntowijoyo يقول أن أحمد رفاعى ينوب عن حر كة أرثودو كية لـ يلمـح مـن مساعيه عن التقاء تعاليم الإسلام فى العقيدة و الشريعة. إن حر كة أحمد رفاعى وتعاليمه لم تنته بوفاته، بل استمرّ تلاميذه فـى إحياء أفكاره

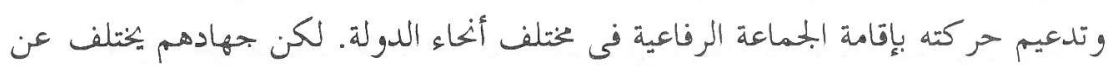

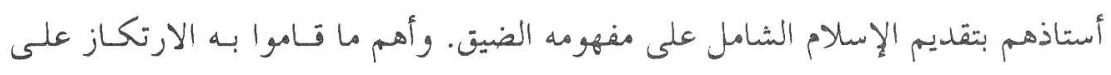

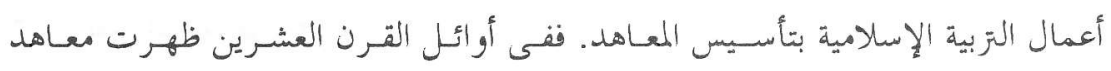

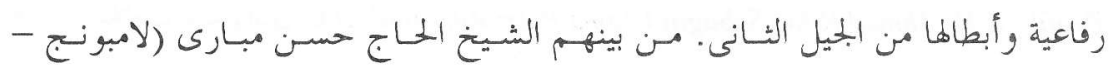

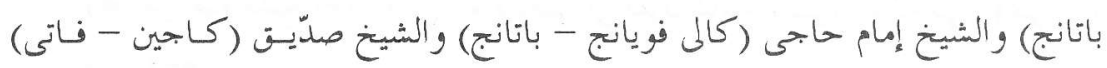

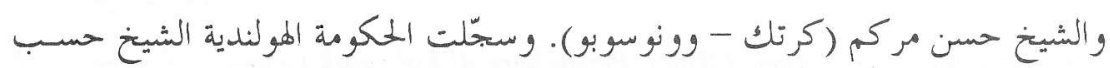

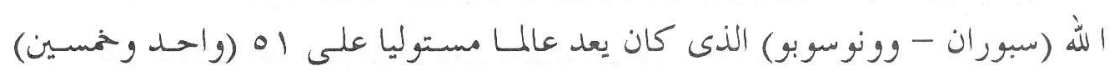

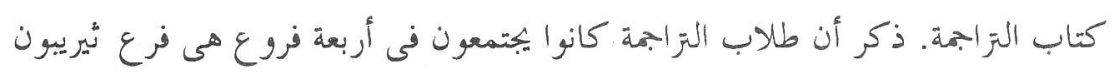

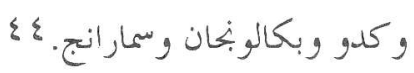

وعندما ننظر إلى شخصية أحمد رفاعى بنده العالم والمؤلف والمبلغ، فليس من المبالغـة

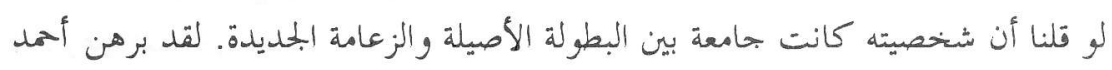

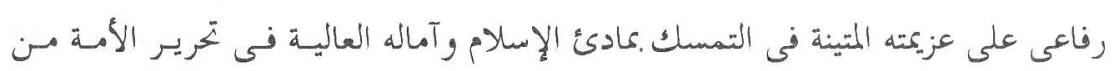

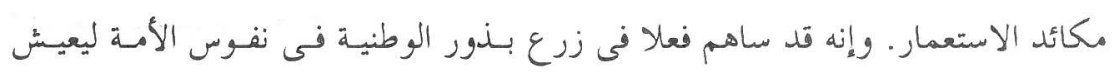
أفر ادها أحرارا سعداء فى دارهم ووطنهم.

الهو امشّ

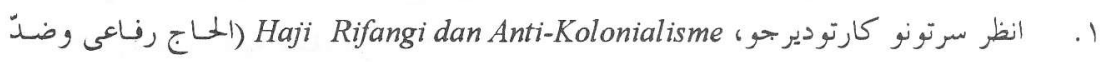

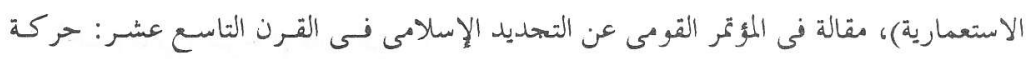

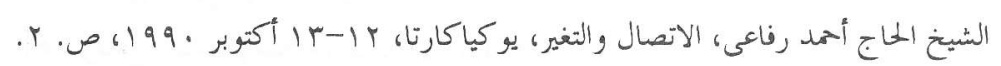

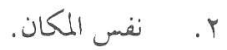




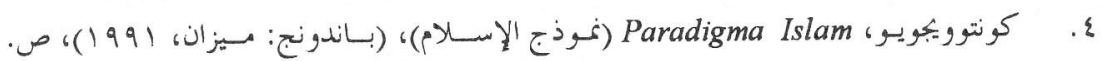

Mengenal Ajaran Tarjumah Syaikh H. Ahmad Rifa'i RH, انظر شـاذرين أمين، 0

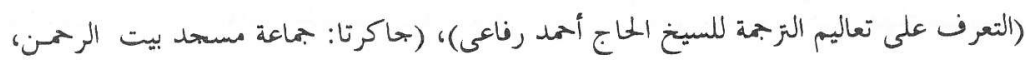

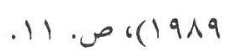

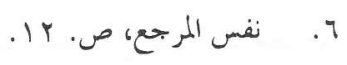

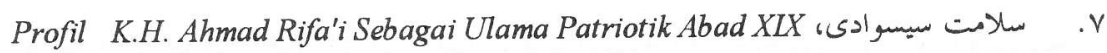
(لعة عن حياة الشيخ أحمد رفاعى كعالم وطنى فى القرن التاسع عشَر)، مقالة في الموتمر .... ص. ع- صن

A. سيف الدين سيمون، Ahmad Rifa'i: Pembaharu di Kalisalak (أحمد رفاعى: بعدد فى

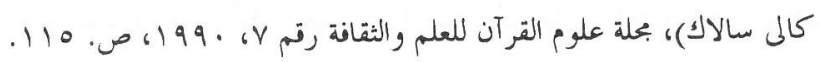

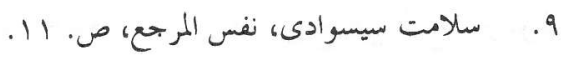

$$
\begin{aligned}
& \text { •1. . سيف الدين سيمون، نفس المرجع، ص. } 117 .
\end{aligned}
$$

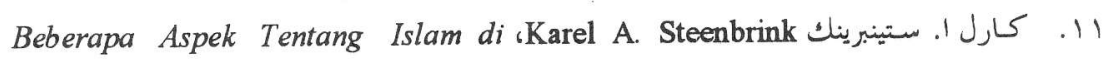
Indonesia Abad ke-19

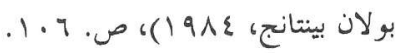

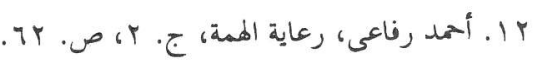

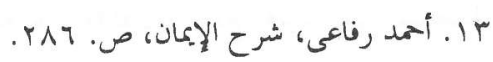

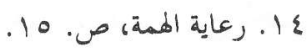

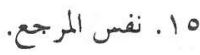

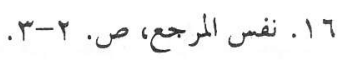

$$
\begin{aligned}
& \text { IV }
\end{aligned}
$$

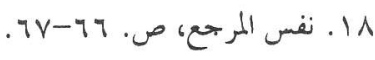

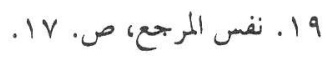

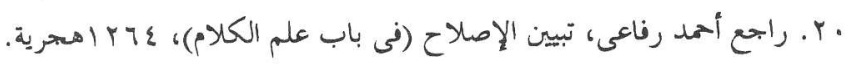

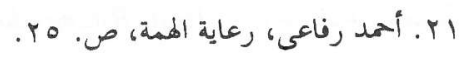

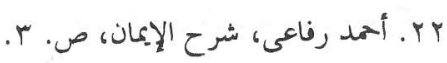

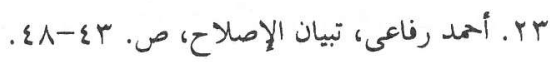

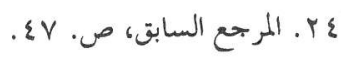




$$
\begin{aligned}
& \text { OY. أحمد رفاعى، رعاية الهمة، ص. ع||-110 }
\end{aligned}
$$

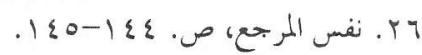

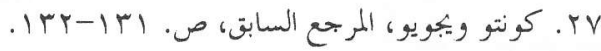

^ ץ. مرشدين رملى، Tasawuf dalam Pandangan K.H. Ahmad Rifa'i (التصـوف عنـد الشيخخ

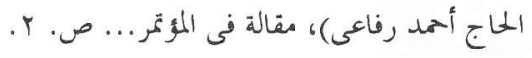

و Y. نفس المرجع، ص. r. . وراجع كتبه الأخرى "تربية الهوى" و "رعاية الهمة" و"حسن المطالب".

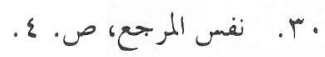

اس. . نفس المرجع، ص. 11 . . ولاحظ كذلك كتاب "رعاية الممة".

rr. r. نفس المرجع، ص. 11 . و وانظر أيضا كتاب "تخيرة".

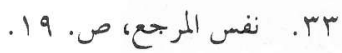

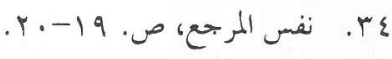

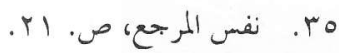

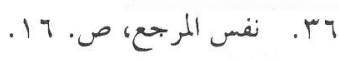

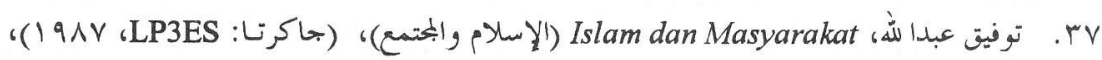

$$
\begin{aligned}
& \text { ص. }
\end{aligned}
$$

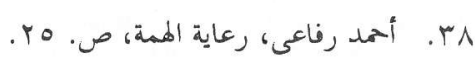

$$
\begin{aligned}
& \text { هั }
\end{aligned}
$$

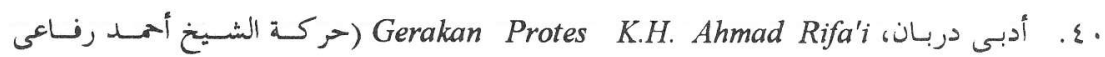

$$
\begin{aligned}
& \text { الاحتحاجية)، مقالة فى المؤتمر...، ص. ع- . 1. }
\end{aligned}
$$

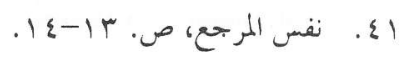

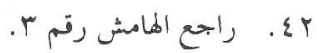

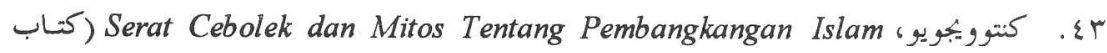

تشيبوليك وأسطورة المعارضة الإسلامية)، بجلة علوم القــرآن للعلم والثقافة، رقـم 0، ـ99 19 ،

$$
\begin{aligned}
& \text { ص. ص } \\
& \text { ع ـ. تفس المر جع، ص. }
\end{aligned}
$$

مخلصين سعل، مدرس بكلية الآداب بمامعة سونان أمبيل الإسلامية الحكومية، سـورابايا؛ طالب بالدراسات العليا بجامعة شريف هداية الله الإسلامية الحلكومية، جاكرتا. 